\title{
Combining ability and heterosis for yield and quality traits in pea (Pisum sativum $\mathbf{L}$.)
}

\author{
Zyada H.G. and Samar A. Bardisi \\ Hort. Dept., Fac. Agric., Zagazig Univ., Egypt \\ *Corresponding author: Email: samarbardisi30@gmail.com - hgzyada@yahoo.com
}

Received on: 15-11-2021

Accepted on: 1-12-2021

\begin{abstract}
Increase pea yield and quality traits are essential goalsin any breeding program. This study was carried out during three winter growing seasons of 2018/2019, 2019/2020, and 2020/ 2021 on pea using diallel mating design (4×4) without reciprocals at Fac. Agric., Zagazig Univ., Egypt. Analysis of variance showed significant and highly significant mean squares for all the studied traits of genotypes, except the TSS trait, which had insignificant. Parent Master B $\left(\mathrm{P}_{2}\right)$ showed positive and significant general combining ability (GCA) effects for pod number/ plant, 100-seed weight, and yield/ plant and parent Entsar $2\left(\mathrm{P}_{4}\right)$ for plant height, plant dry weight, pod length, pod diameter, and seed number/pod. The pea cross Little Marvel $\left(\mathrm{P}_{3}\right) \times$ Entsar $2\left(\mathrm{P}_{4}\right)$ had the highest values of mean and desirable effects of specific combining ability (SCA) for yield/ plant and pod number/ plant. Additive gene action was controlled plant height, plant dry weight, pod length, pod diameter, seed number/pod, pod number/plant, TSS, and protein content, while nonadditive controlled the rest characters. Cross Cambados $\left(\mathrm{P}_{1}\right) \times$ Little Marvel $\left(\mathrm{P}_{3}\right)$ exhibited positive and significant SCA effects for branch number, plant dry weight, pod length, seed number/pod, and TSS. Positive and significant heterosis values were recorded in crosses $\mathrm{P}_{3} \times \mathrm{P}_{4}$ andP $\mathrm{P}_{2} \times \mathrm{P}_{3}$ for yield/ plant and pod number/ plant. Therefore, these genotypes could be used in the future program to improve pea yield.
\end{abstract}

KEYWORDS: Pea (Pisum sativum L.), Diallel cross, GCA, SCA, Heterosis, Yield traits.

\section{INTRODUCTION}

Pea (Pisum sativum L.) is the second most important food legume crop after common bean (Kumari et al. 2013). Pea is one of the edible legumes or pulse crops, and one of the most popular vegetable crops all over the world and in Egypt. The world's production of pea is fourth after soybean, peanuts, and dry beans (Smykal et al., 2012).The major goal for pea breeding is to develop highyielding varieties with stable yields (Abo-Hamda 2019).

Hybridization has been still the main important used method in improving the yield and quality of many vegetable crops. In this connection, pea seems to have received little attention and consequently, genetic information in all characteristics of pea is needed for wide inter varietal crosses to design accurate plans and efficient breeding programs A diallel method of crossing based on the data of $F_{1}$ hybrids is an accurate method for its determination (Suman et al., 2017 and Manjunath et al.,2020).

Diallel technique analysis of Hayman (1954 a, b) has been effectively used in self and crosspollinated crops to provide a picture of the genetic behavior of the parents and the extent of the nature of heterosis, additive and non-additive effects, contributing to the phenotypic variance for a particular trait.

Combining ability analysis helps the breeder in identifying potential parents either to be used for heterosis breeding or for hybridization to select desirable pure line varieties through pedigree, bulk, and back cross methods (Nassef and El-Rawy, 2013). In self-pollinated crops like pea, these studies are useful in assessing the combining ability of the parents which, when crossed, would give more desirable segregates. Suman et al., (2017) and Manjunath et al., (2020) observed that both general and specific combining abilities were important for hundred seed weight and the number of seeds per pod. Also, Al-Hamdany (2014) and Askander et al., (2018) reported that general combining ability was significant for the traits plant height, 100 seeds weight, and pod weight but non-significant for seeds pod, while SCA for most characters was significant in pea.

Heterosis breeding depends upon the basic genetic information of varied genotypes, which could be helpful if the heterosisis organized in a specific cross of a considerable magnitude. Such heterosis could be exploited in establishing a hybrid variety, or when subjected to self-pollination to get the proceeding segregation generations to isolate pure lines better than its better parent or better than its $\mathrm{F}_{1}$-hybrids.Positive heterosis over the better 
parent for plant length was ranged from $6.44 \%$ to 104.21\%(Hamed et al., 2015). El-Dakkak (2016) found negative heterosis $(-16.82 \%)$ based on the tallest parent for this trait. Furthermore, significant and positive heterosis for grain yield/ plant was observed inseven hybrids (Askander et al.2018).

Genetically studies; i.e., estimates of general and specific combining ability (GCA and SCA) are valuable for plant breeders, when planning a breeding program. In addition, heterosis breeding, depending on the basic genetic information of varied genotypes, would be helpful, if the heterosisis organized in a specific cross of a considerable magnitude (Hassan, 2012; Manjunath et al., 2020 and Gharib, 2021).

Therefore, the present study on pea aimed to get information about the inheritance, genetic parameters, and magnitude of heterosis and combining ability for some important traits in pea using the diallel cross system.

\section{MATERIALS AND METHODS}

The present study was carried out during three winter growing seasons of 2019, 2020 and 2021 on pea, at Fac. Agric., Zagazig Univ., Egypt. This was initiated to study the heterosis of some pea genotypes, using diallel mating design $(4 \times 4)$ without reciprocals. The four cultivars used were Cambados $\left(\mathrm{P}_{1}\right)$, Master B $\left(\mathrm{P}_{2}\right)$, Little Marvel $\left(\mathrm{P}_{3}\right)$, and Entsar 2 $\left(\mathrm{P}_{4}\right)$.

\subsection{Experimental Procedure}

In the 2018/ 2019 season (26 December), the used cultivars were selfed for one season, to get selfed seeds. In the 2019/ 2020 season (14 October), the four cultivars were raised in the field and crosshand pollination at the flowering stage was done, according to diallel mating design to produce six $F_{1}$ hybrid seeds. In the 2020/ 2021 season, the six $F_{1}$ hybrids with the four parents were sown on $14^{\text {th }}$ October 2020and tested in a completely randomized block design with three replicates. Each experimental unit contained one ridge. Each ridge was $3 \mathrm{~m}$ long. The entries in each experimental unit consisted of 30 plants, planted at a spacing of $10 \times 60$ $\mathrm{cm}$. Cultural practices; i.e., irrigation, fertilization, and pests, and weed control were practiced in suitable time as recommended for pea.

\subsection{Data Recorded}

Observations on morphological traits; i.e., plant height $(\mathrm{cm})$ it was measured at the end of seasons, branch number per plant (it was counted at the end of seasons), plant dry weight ( $\mathrm{g}$ ),pod length $(\mathrm{cm})$, pod diameter $(\mathrm{cm})$, seed number per pod and 100-seed weight (g), yield traits; i.e., pod number per plant, pod weight and total yield per plant (ended by
6 Feb. 2021), and quality traits; i.e., TSS (Brix $\left.{ }^{\circ}\right)$ and protein $(\%)$, were recorded.

\subsection{Statistical Analysis}

All the obtained data were subjected to the analysis of variance according to the method described for completely randomized block design by Snedecor and Cochran (1967). Mean squares were further partitioned to parents (with 3d.f.), crosses (with 5d.f.), and residual (parents vs. crosses, with 1 d.f.).General and specific combining ability were calculated according to Method II Model II proposed by Griffing (1956). Also, additive and dominance portions were calculated from the expected mean squares.

Where:

$$
\sigma_{\mathrm{A}}^{2}=2 \sigma_{\mathrm{g}}^{2} \text { and } \sigma_{\mathrm{D}}^{2}=\sigma_{\mathrm{S}}^{2}
$$

$\boldsymbol{\sigma}_{\mathrm{A}}^{2}$ : Additive component of variation.

$\sigma_{\mathrm{D}}^{2}$ : Dominance component of variation.

$\boldsymbol{\sigma}_{\mathrm{g}}^{2}$ : Variance due to general combining ability.

$\boldsymbol{\sigma}^{2}$ : Variance due to specific combining ability.

Heterosis was calculated over mid-parent (MP)and over better parent (BP), according to Rai (1979) as follows:

a. Mid-parent heterosis $(\mathrm{MP})=\left[\left(\mathrm{F}_{1}-\mathrm{MP}\right) / \mathrm{MP}\right] \times 100$

b. Better parent heterosis $(\mathrm{BP})=\left[\left(\mathrm{F}_{1}-\mathrm{BP}\right) / \mathrm{BP}\right] \times 100$

The LSD values were calculated to test the significance of this component of heterotic effect, according to the following formula:

LSD for MP heterosis $=\operatorname{tp}_{\%} \times \sqrt{2} \mathrm{MSe} / \mathrm{r}$

Where:

tp \%: Is a tabulated $t$ value at the stated level of probability for experimental error degree of freedom.

MSe : Is the mean squares of the experimentalerror for the analysis of variance.

$\mathbf{r}:$ Is the number of replications.

$\mathbf{F}_{1}$ : The first filial generation.

\section{RESULTS}

The results of analysis of variance for $4 \times 4$ diallel cross system were conducted for some growth traits (plant height, number of branches/ plant and dry weight/ plant), yield and its components (pod length, pod diameter, number of seed/ pod, 100-seed weight, number of pods/ plant, average pod weight and yield/ plant) and quality traits (TSS and proteins), to study mean performance of genotypes resulted from the diallel cross system, GCA, SCA, and heterosis presented in these traits of pea.

\subsection{Mean performance}

Analysis of variance as shown in Table 1 showed significant and highly significant mean squares for all the studied traits of genotypes, except the TSS trait which had insignificant. 
Scientific Journal of Agricultural Sciences 3 (2): 78-86, 2021

Table 1. Mean squares of general (GCA), specific (SCA) combining ability and ratio of $\sigma_{\text {gea }}^{2} \sigma_{\text {sca }}^{2}$ resulted from $4 \times 4$ diallel cross system for growth, yield and quality traits of pea in the winter season of $2020 / 2021$

\begin{tabular}{|c|c|c|c|c|c|c|c|c|c|c|c|c|c|}
\hline \multirow[b]{2}{*}{ S.O.V } & \multirow[b]{2}{*}{ d.f. } & \multicolumn{3}{|c|}{ Growth traits } & \multicolumn{7}{|c|}{ Yield and its components traits } & \multicolumn{2}{|c|}{ Quality traits } \\
\hline & & $\begin{array}{c}\text { Plant } \\
\text { height } \\
(\mathrm{cm})\end{array}$ & $\begin{array}{c}\text { Branch } \\
\text { No. }\end{array}$ & $\begin{array}{c}\text { Plant } \\
\text { dry wt. } \\
\text { (gm) }\end{array}$ & $\begin{array}{c}\text { Pod } \\
\text { length } \\
(\mathrm{cm}) \\
\end{array}$ & $\begin{array}{c}\text { Pod } \\
\text { diameter } \\
(\mathbf{c m}) \\
\end{array}$ & $\begin{array}{c}\text { Seed } \\
\text { No./pod }\end{array}$ & $\begin{array}{c}\text { 100-Seed } \\
\text { wt.(gm) }\end{array}$ & $\begin{array}{c}\text { Pod } \\
\text { No./plant }\end{array}$ & $\begin{array}{c}\text { Pod } \\
\text { wt. } \\
\text { (gm) } \\
\end{array}$ & $\begin{array}{c}\text { Yield/plant } \\
\text { (g) }\end{array}$ & $\begin{array}{c}\text { TSS } \\
\left(\text { Brix }^{\circ}\right)\end{array}$ & $\begin{array}{c}\text { Protein } \\
(\%)\end{array}$ \\
\hline Reps & 2 & $291.33^{* * *}$ & $1.63^{\mathrm{NS}}$ & $0.01^{\mathrm{NS}}$ & $0.17^{\mathrm{NS}}$ & $0.00^{\mathrm{NS}}$ & $0.23^{\mathrm{NS}}$ & $25.60^{* *}$ & $8.23^{\mathrm{NS}}$ & $0.11^{\mathrm{NS}}$ & $28.90^{\mathrm{NS}}$ & $9.26^{\mathrm{NS}}$ & $0.01^{\mathrm{NS}}$ \\
\hline Genotypes & 9 & $485.06^{* *}$ & $4.08^{* * *}$ & $193.06^{* * *}$ & $3.01^{* *}$ & $0.04^{* *}$ & $4.48^{* *}$ & $79.58^{* *}$ & $79.63^{* *}$ & $0.54^{*}$ & $3648.71^{* *}$ & $24.08^{\mathrm{NS}}$ & $14.66^{* *}$ \\
\hline Parents (P) & 3 & $1037.88^{* * *}$ & $4.44^{* *}$ & $243.67^{* *}$ & $5.37^{* *}$ & $0.05^{* *}$ & $5.00^{* * *}$ & $38.81^{* *}$ & $10.44^{\mathrm{NS}}$ & $0.49^{\mathrm{NS}}$ & $679.57^{\mathrm{NS}}$ & $30.05^{\mathrm{NS}}$ & $7.42^{* *}$ \\
\hline Crosses (C) & 5 & $162.36^{* * *}$ & $3.92^{* *}$ & $152.82^{* *}$ & $1.95^{* *}$ & $0.02^{*}$ & $4.99^{* *}$ & $37.57^{* *}$ & $113.39^{* *}$ & $0.31^{\mathrm{NS}}$ & $5938.22^{* * *}$ & $16.40^{\mathrm{NS}}$ & $19.36^{* *}$ \\
\hline P vs. C & 1 & $440.08^{* *}$ & $3.76^{*}$ & $242.44^{* * *}$ & $1.20^{*}$ & $0.12^{* *}$ & $0.36^{\mathrm{NS}}$ & $411.93^{* *}$ & $118.42^{* * *}$ & $1.85^{* *}$ & $1108.56^{\mathrm{NS}}$ & $44.54^{\mathrm{NS}}$ & $12.90^{* *}$ \\
\hline GCA & 3 & $658.96^{* *}$ & $0.35^{\mathrm{NS}}$ & $382.57^{* *}$ & $6.65^{* *}$ & $0.04^{* *}$ & $11.20^{* *}$ & $31.85^{* *}$ & $80.98^{* *}$ & $0.43^{\mathrm{NS}}$ & $3047.46^{* * *}$ & $29.90^{\mathrm{NS}}$ & $15.80^{* *}$ \\
\hline SCA & 6 & $398.11^{* *}$ & $5.94^{* *}$ & $98.30^{* *}$ & $1.19^{* *}$ & $0.04^{* *}$ & $1.11^{* * *}$ & $103.44^{* *}$ & $78.96^{* *}$ & $0.60^{*}$ & $3949.33^{* *}$ & $21.17^{\mathrm{NS}}$ & $14.09^{* * *}$ \\
\hline Error & 18 & 22.19 & 0.52 & 5.13 & 0.16 & 0.00 & 0.12 & 3.25 & 4.34 & 0.18 & 287.45 & 15.56 & 0.03 \\
\hline$\sigma_{\mathrm{GCA}}^{2} / \sigma_{\mathrm{SCA}}^{2}$ & & 1.66 & 0.06 & 3.89 & 5.61 & 1.23 & 10.05 & 0.31 & 1.03 & 0.72 & 0.77 & 1.41 & 1.12 \\
\hline
\end{tabular}

$\mathrm{NS}, *$, and $* *$ are insignificant, significant, and highly significant at 5\% and 1\% levels of probability, respectively. 


\section{Zyada H.G. and Samar A. Bardisi., 2021}

As for parents, mean squares for parents showed highly significant for all the studied traits, except the number of pods/ plant, average pod weight, and TSS which had insignificant. Crosses reflected significant and highly significant for all the studied traits, except average pod weight and TSS which were insignificant. Concerning mean squares of parents vs. crosses, mean squares of $\mathrm{P} v s \mathrm{C}$ showed significant and highly significant for all the traits, except seed number/ pod, yield/ plant, and TSS which were insignificant.

As for the analysis of variance for GCA and SCA, data in Table 1 showed that mean squares of GCA and SCA were significant and highly significant for all the studied traits, except the number of branches/ plant, average pod weight, and TSS for GCA and TSS for SCA which were insignificant. For genetic components $\left(\sigma_{\mathrm{A}}^{2}\right.$ and $\left.\sigma_{\mathrm{D}}^{2}\right)$ resulting from analysis of variance for GCA and SCA, data in Table 1 showed that values of $\sigma_{\text {GCA }}^{2}$ (additive component)and $\sigma_{\text {SCA }}^{2}$ (dominance component)were positive in all the cases. The values of $\sigma_{\mathrm{GCA}}^{2}$ were larger than $\sigma_{\mathrm{SCA}}^{2}$ for plant height, plant dry weight, pod length, pod diameter, seed number/ pod, pod number/ plant, TSS and protein content, while the values of $\sigma_{\text {SCA }}^{2}$ was larger than $\sigma^{2}{ }_{\mathrm{GCA}}$ for the number of branches/ plant, 100-seed weight, average pod weight and yield/ plant as shown from the ratio of variance GCA/ variance SCA (Table1).

\subsection{Mean values of parents and $F 1$ hybrids}

Since the parents had high variability, the parents (Table 2) scored high and low values, respectively; i.e., $\mathrm{P}_{4}$ and $\mathrm{P}_{2}$ for both plant height and plant dry weight; $\mathrm{P}_{4}$ and $\mathrm{P}_{1}$ for the number of branches/ plant; $\mathrm{P}_{4}$ and $\mathrm{P}_{3}$ for pod length; $\mathrm{P}_{4}$ and $\mathrm{P}_{2}$ for pod diameter; $\mathrm{P}_{1}$ and $\mathrm{P}_{2}$ for seed number/ pod; $\mathrm{P}_{4}$ and $\mathrm{P}_{1}$ for 100 -seed weight $\mathrm{P}_{2}$ and $\mathrm{P}_{1}$ for average pod number/ plant; $\mathrm{P}_{3}$ and $\mathrm{P}_{2}$ for both average pod weight and yield/ plant; $\mathrm{P}_{4}$ and $\mathrm{P}_{3}$ for TSS and $\mathrm{P}_{2}$ and $\mathrm{P}_{4}$ for protein content.

For crosses (Table 2), the high and low values respectively were produced from $\mathrm{P}_{3} \times \mathrm{P}_{4}$ and $\mathrm{P}_{1} \times \mathrm{P}_{4}$ for plant height; from $\mathrm{P}_{1} \times \mathrm{P}_{3}$ and $\mathrm{P}_{1} \times \mathrm{P}_{4}$ for both the number of branches/ plant and plant dry weight; from $\mathrm{P}_{1} \times \mathrm{P}_{3}$ and $\mathrm{P}_{1} \times \mathrm{P}_{2}$ for pod length; from $\mathrm{P}_{2} \times \mathrm{P}_{4}$ and $\mathrm{P}_{2} \times \mathrm{P}_{3}$ for pod diameter; from $\mathrm{P}_{1} \times \mathrm{P}_{4}$ and $\mathrm{P}_{2} \times \mathrm{P}_{3}$ for seed number/ pod; from $\mathrm{P}_{2} \times \mathrm{P}_{3}$ and $\mathrm{P}_{1} \times \mathrm{P}_{4}$ for 100-seed weight; from $\mathrm{P}_{3} \times \mathrm{P}_{4}$ and $\mathrm{P}_{1} \times \mathrm{P}_{4}$ for pod number/ plant; from $\mathrm{P}_{1} \times \mathrm{P}_{4}$ and $\mathrm{P}_{2} \times \mathrm{P}_{3}$ for average pod weight; from $\mathrm{P}_{3} \times \mathrm{P}_{4}$ and $\mathrm{P}_{1} \times \mathrm{P}_{3}$ for yield/ plant; from $\mathrm{P}_{1} \times \mathrm{P}_{3}$ and $\mathrm{P}_{3} \times \mathrm{P}_{4}$ for TSS, and from $\mathrm{P}_{2} \times \mathrm{P}_{3}$ and $\mathrm{P}_{1} \times \mathrm{P}_{3}$ for protein content.

\subsection{General combining ability (GCA) effects}

According to GCA value (Table 3), the best combiners were $\mathrm{P}_{3}$ and $\mathrm{P}_{4}$ for plant height, $\mathrm{P}_{1}$ and $\mathrm{P}_{4}$ for plant dry weight, $\mathrm{P}_{1}$ and $\mathrm{P}_{4}$ for pod length, $\mathrm{P}_{4}$ for pod diameter, $\mathrm{P}_{1}$ and $\mathrm{P}_{4}$ for seed number/ pod, $\mathrm{P}_{1}$ and $\mathrm{P}_{2}$ for 100 -seed weight, $\mathrm{P}_{3}$ and $\mathrm{P}_{2}$ for pod number/ plant and $\mathrm{P}_{2}$ for yield/ plant and protein content.

\subsection{Heterosis}

\subsubsection{Growth traits}

For heterosis in plant height (Table 5), data show that mid-parent (MP) heterosis was negative for all the crosses obtained from $4 \times 4$ diallel mating design, except the crosses $\mathrm{P}_{1} \times \mathrm{P}_{2}$ and $\mathrm{P}_{2} \times \mathrm{P}_{3}$ which were positive heterosis. Heterosis in plant height reached $(25.72 \%)$ in the cross $\mathrm{P}_{1} \times \mathrm{P}_{2}$ followed by $\mathrm{P}_{2} \times \mathrm{P}_{3}(4.99 \%)$ over mid-parent. For branch number/ plant, positive heterosis was present in most of the crosses when calculated from MP, reached $62.50 \%$ in the cross $\mathrm{P}_{2} \times \mathrm{P}_{3}$ followed by $27.78 \%\left(\mathrm{P}_{1} \times \mathrm{P}_{2}\right)$, $21.05 \%\left(\mathrm{P}_{1} \times \mathrm{P}_{4}\right)$, and $5.28 \%\left(\mathrm{P}_{2} \times \mathrm{P}_{3}\right.$ over the mid parent. For plant dry weight, data show that MP heterosis was negative for all the cases, except the cross $\mathrm{P}_{1} \times \mathrm{P}_{3}$ had positive heterosis.

\subsubsection{Yield and its components}

Data in Table 5 show that heterosis for pod length, pod diameter, number of seed/ pod, and 100seed weight was negative for all the cases, except the crosses $\mathrm{P}_{1} \times \mathrm{P}_{2}$ and $\mathrm{P}_{1} \times \mathrm{P}_{3}$ were positive for pod length, and $\mathrm{P}_{1} \times \mathrm{P}_{2}$ and $\mathrm{P}_{1} \times \mathrm{P}_{4}$ for seed number/ pod.

As for heterosis in average pod number/ plant, data in Table 5 show that MP heterosis was positive for all the crosses, except the cross $\mathrm{P}_{1} \times \mathrm{P}_{4}$ had negative heterosis. Heterosis for average pod number/ plant reached $46.51 \%$ in the cross $\mathrm{P}_{3} \times$ $\mathrm{P}_{4}$ followed by $21.29 \%\left(\mathrm{P}_{2} \times \mathrm{P}_{4}\right), 13.67 \%\left(\mathrm{P}_{2} \times \mathrm{P}_{3}\right)$, $9.52 \%\left(\mathrm{P}_{1} \times \mathrm{P}_{2}\right)$, and $2.99 \%\left(\mathrm{P}_{1} \times \mathrm{P}_{3}\right)$ over the mid parent.

Heterosis in average pod weight, data show that $\mathrm{MB}$ heterosis was negative, except one cross $\left(\mathrm{P}_{1} \times \mathrm{P}_{4}\right)$ which had positive heterosis.

Respecting for yield/ plant, MP heterosis reached $70.63 \%$ in the cross $\mathrm{P}_{3} \times \mathrm{P}_{4}$ followed by $17.01 \%\left(\mathrm{P}_{2} \times \mathrm{P}_{3}\right)$ and $7.04 \%\left(\mathrm{P}_{2} \times \mathrm{P}_{4}\right)$ over the mid parent. In contrast, the crosses $\mathrm{P}_{1} \times \mathrm{P}_{2}, \mathrm{P}_{1} \times \mathrm{P}_{3}$ and $\mathrm{P}_{1} \times \mathrm{P}_{4}$ showed negative heterosis for this trait.

\subsubsection{Pod quality traits}

For heterosis in TSS data in Table 5 show that MP heterosis was positive for all the crosses, except the cross $\mathrm{P}_{1} \times \mathrm{P}_{4}$ had negative heterosis. The best heterosis over MP was observed with crosses, $\mathrm{P}_{1} \times \mathrm{P}_{3}$ (37.85\%), $\mathrm{P}_{2} \times \mathrm{P}_{3}(22.71 \%), \mathrm{P}_{2} \times \mathrm{P}_{4}(10.40 \%), \mathrm{P}_{1} \times \mathrm{P}_{2}$ (9.72\%), and $\mathrm{P}_{2} \times \mathrm{P}_{4}(1.80 \%)$.

For heterosis in protein content, data in Table 5 show that MP heterosis was negative for all the crosses, except the crosses $\mathrm{P}_{1} \times \mathrm{P}_{4}$ and $\mathrm{P}_{2} \times \mathrm{P}_{4}$ which had positive heterosis $(4.71 \%$ and $0.27 \%$, respectively). 
Scientific Journal of Agricultural Sciences 3 (2): 78-86, 2021

Table 2.Mean performance of parental genotypes and $F_{1}$-hybrids resulted from $4 \times 4$ diallel cross system for growth, yield and quality traits of pea in the winter season of 2020/ 2021

\begin{tabular}{|c|c|c|c|c|c|c|c|c|c|c|c|c|}
\hline \multirow[b]{2}{*}{ Genotypes } & \multicolumn{3}{|c|}{ Growth traits } & \multicolumn{7}{|c|}{ Yield and its components traits } & \multicolumn{2}{|c|}{ Quality traits } \\
\hline & $\begin{array}{c}\text { Plant } \\
\text { height } \\
\text { (cm) }\end{array}$ & $\begin{array}{c}\text { Branch } \\
\text { No. }\end{array}$ & $\begin{array}{c}\text { Plant } \\
\text { dry wt. } \\
\text { (gm) }\end{array}$ & $\begin{array}{c}\text { Pod } \\
\text { length } \\
(\mathrm{cm}) \\
\end{array}$ & $\begin{array}{c}\text { Pod } \\
\text { diameter } \\
(\mathrm{cm})\end{array}$ & $\begin{array}{c}\text { Seed } \\
\text { No./pod }\end{array}$ & $\begin{array}{c}\text { 100-Seed } \\
\text { wt.(gm) }\end{array}$ & $\begin{array}{c}\text { Pod } \\
\text { No./plant }\end{array}$ & $\begin{array}{l}\text { Pod wt. } \\
\text { (gm) }\end{array}$ & $\begin{array}{c}\text { Yield/plant } \\
\text { (g) }\end{array}$ & $\begin{array}{c}\text { TSS } \\
\left(\text { Brix }^{\circ}\right)\end{array}$ & $\begin{array}{c}\text { Protein } \\
(\%)\end{array}$ \\
\hline $\mathbf{P}_{1}$ & 53.54 & 5.00 & 30.10 & 9.97 & 1.30 & 10.00 & 47.00 & 26.00 & 5.13 & 135.67 & 21.87 & 18.40 \\
\hline $\mathbf{P}_{2}$ & 43.25 & 7.00 & 15.27 & 8.07 & 1.20 & 7.00 & 52.00 & 30.00 & 5.51 & 165.50 & 17.14 & 21.33 \\
\hline $\mathbf{P}_{3}$ & 74.63 & 5.67 & 22.30 & 7.80 & 1.20 & 8.00 & 52.00 & 29.67 & 4.64 & 134.60 & 15.57 & 19.94 \\
\hline $\mathbf{P}_{4}$ & 83.63 & 7.67 & 35.90 & 10.47 & 1.47 & 9.00 & 55.77 & 27.67 & 4.71 & 136.00 & 21.57 & 17.85 \\
\hline $\mathbf{P}_{1} \times \mathbf{P}_{2}$ & 60.84 & 7.67 & 17.30 & 9.27 & 1.20 & 7.67 & 48.00 & 30.67 & 4.45 & 135.20 & 21.40 & 17.31 \\
\hline $\mathbf{P}_{1} \times \mathbf{P}_{3}$ & 53.50 & 8.67 & 28.17 & 9.17 & 1.17 & 9.67 & 41.00 & 28.67 & 4.00 & 111.90 & 25.80 & 13.35 \\
\hline $\mathbf{P}_{1} \times \mathbf{P}_{4}$ & 43.23 & 7.67 & 22.90 & 8.80 & 1.17 & 10.00 & 41.00 & 24.00 & 4.97 & 117.20 & 21.60 & 18.98 \\
\hline $\mathbf{P}_{\mathbf{2}} \times \mathbf{P}_{\mathbf{3}}$ & 61.88 & 6.67 & 13.27 & 7.10 & 1.10 & 6.67 & 48.50 & 34.00 & 4.34 & 175.57 & 20.07 & 20.52 \\
\hline $\mathbf{P}_{2} \times \mathbf{P}_{4}$ & 53.96 & 5.67 & 11.50 & 9.07 & 1.27 & 8.00 & 41.27 & 35.00 & 4.60 & 161.37 & 21.37 & 19.65 \\
\hline $\mathbf{P}_{3} \times \mathbf{P}_{4}$ & 62.25 & 6.00 & 27.40 & 8.60 & 1.07 & 7.67 & 45.00 & 42.00 & 4.58 & 230.87 & 18.90 & 18.44 \\
\hline Mean & 59.07 & 6.77 & 22.41 & 8.83 & 1.21 & 8.37 & 47.15 & 32.80 & 4.69 & 150.39 & 20.53 & 18.58 \\
\hline LSD at $5 \%$ & 8.08 & 1.24 & 3.89 & 0.68 & 0.12 & 0.60 & 3.09 & 3.58 & 0.73 & 29.08 & 6.77 & 0.30 \\
\hline $\mathrm{CV} \%$ & 7.97 & 10.68 & 10.11 & 4.51 & 5.78 & 4.18 & 3.82 & 20.49 & 9.01 & 11.27 & 19.22 & 0.95 \\
\hline
\end{tabular}

$\mathrm{P}_{1}, \mathrm{P}_{2}, \mathrm{P}_{3}$, and $\mathrm{P}_{4}$ are Cambados, Master $\mathrm{B}$, Little Marvel, and Entsar 2, respectively.

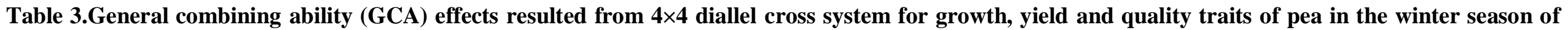
2020/ 2021

\begin{tabular}{|c|c|c|c|c|c|c|c|c|c|c|c|c|}
\hline \multirow[b]{2}{*}{ Parents } & \multicolumn{3}{|c|}{ Growth traits } & \multicolumn{5}{|c|}{ Yield and its components traits } & \multicolumn{4}{|c|}{ Quality traits } \\
\hline & $\begin{array}{c}\text { Plant } \\
\text { height } \\
\text { (cm) }\end{array}$ & $\begin{array}{c}\text { Branch } \\
\text { No. }\end{array}$ & $\begin{array}{c}\text { Plant } \\
\text { dry wt. } \\
\text { (gm) }\end{array}$ & $\begin{array}{c}\text { Pod } \\
\text { length } \\
(\mathrm{cm}) \\
\end{array}$ & $\begin{array}{c}\text { Pod } \\
\text { diameter } \\
(\mathbf{c m})\end{array}$ & $\begin{array}{c}\text { Seed } \\
\text { No./pod }\end{array}$ & $\begin{array}{l}\text { 100-Seed } \\
\text { wt.(gm) }\end{array}$ & $\begin{array}{c}\text { Pod } \\
\text { No./plant }\end{array}$ & $\begin{array}{l}\text { Pod wt. } \\
\text { (gm) }\end{array}$ & $\begin{array}{c}\text { Yield/plant } \\
\text { (g) }\end{array}$ & $\begin{array}{c}\text { TSS } \\
\left(\text { Brix }^{\circ}\right)\end{array}$ & $\begin{array}{c}\text { Protein } \\
(\%)\end{array}$ \\
\hline $\mathbf{P}_{1}$ & $-5.12^{* * *}$ & $0.03^{\mathrm{NS}}$ & $2.75^{* * *}$ & $0.50^{* * *}$ & $0.01^{\mathrm{NS}}$ & $0.92^{* * *}$ & $-1.96^{* * *}$ & $-3.08^{* * *}$ & $0.04^{\mathrm{NS}}$ & $-19.38^{* *}$ & $1.65^{\mathrm{NS}}$ & $-1.07^{* * *}$ \\
\hline $\mathbf{P}_{2}$ & $-5.36^{* * *}$ & $0.03^{\mathrm{NS}}$ & $-6.58^{* *}$ & $-0.43^{* * *}$ & $-0.02^{\mathrm{NS}}$ & $-0.92^{* * *}$ & $1.00^{*}$ & $0.97^{*}$ & $0.16^{\mathrm{NS}}$ & $8.53^{*}$ & $-0.92^{\mathrm{NS}}$ & $1.21^{\text {*** }}$ \\
\hline $\mathbf{P}_{3}$ & $5.26^{* *}$ & $-0.19^{\mathrm{NS}}$ & $0.23^{\mathrm{NS}}$ & $-0.61^{* *}$ & $-0.06^{* * *}$ & $-0.31^{* * *}$ & $0.46^{\mathrm{NS}}$ & $1.69^{* * *}$ & $-0.21^{*}$ & $5.93^{\mathrm{NS}}$ & $-1.12^{\mathrm{NS}}$ & $-0.12^{* *}$ \\
\hline $\mathbf{P}_{4}$ & $5.22^{* *}$ & $0.14^{\mathrm{NS}}$ & $3.59^{* *}$ & $0.54^{* *}$ & $0.06^{* * *}$ & $0.31^{* *}$ & $0.51^{\mathrm{NS}}$ & $0.42^{\mathrm{NS}}$ & $0.02^{\mathrm{NS}}$ & $4.92^{\mathrm{NS}}$ & $0.39^{\mathrm{NS}}$ & $-0.02^{\mathrm{NS}}$ \\
\hline $\begin{array}{l}\text { LSD at } \\
5 \%\left(g_{i}-g_{i}\right)\end{array}$ & 3.30 & 0.51 & 1.59 & 0.28 & 0.05 & 0.24 & 1.26 & 1.46 & 0.30 & 11.87 & 2.76 & 0.12 \\
\hline
\end{tabular}

$\mathrm{P}_{1}, \mathrm{P}_{2}, \mathrm{P}_{3}$, and $\mathrm{P}_{4}$ are Cambados, Master B, Little Marvel, and Entsar 2, respectively. 
Zyada H.G. and Samar A. Bardisi., 2021

Table 4. Specific combining ability (SCA) effects resulted from $4 \times 4$ diallel cross system for growth, yield and quality traits of pea in the winter season of 2020/ 2021

\begin{tabular}{|c|c|c|c|c|c|c|c|c|c|c|c|c|}
\hline \multirow[b]{2}{*}{ Crosses } & \multicolumn{3}{|c|}{ Growth traits } & \multicolumn{7}{|c|}{ Yield and its components traits } & \multicolumn{2}{|c|}{ Quality traits } \\
\hline & $\begin{array}{l}\text { Plant } \\
\text { height } \\
\text { (cm) }\end{array}$ & $\begin{array}{l}\text { Branch } \\
\text { No. }\end{array}$ & $\begin{array}{l}\text { Plant } \\
\text { dry wt. } \\
\text { (gm) }\end{array}$ & $\begin{array}{l}\text { Pod } \\
\text { length } \\
(\mathrm{cm})\end{array}$ & $\begin{array}{l}\text { Pod } \\
\text { diameter } \\
(\mathrm{cm})\end{array}$ & $\begin{array}{l}\text { Seed } \\
\text { No./pod }\end{array}$ & $\begin{array}{l}\text { 100-Seed } \\
\text { wt.(gm) }\end{array}$ & $\begin{array}{l}\text { Pod } \\
\text { No/plant. }\end{array}$ & $\begin{array}{l}\text { Pod wt. } \\
\text { (gm) }\end{array}$ & $\begin{array}{l}\text { Yield/plant } \\
\text { (g) }\end{array}$ & $\begin{array}{l}\text { TSS } \\
\left(\text { Brix }^{\circ}\right)\end{array}$ & $\begin{array}{l}\text { Protein } \\
(\%)\end{array}$ \\
\hline $\mathbf{P}_{1} \times \mathbf{P}_{2}$ & $12.25^{* * *}$ & $0.84^{*}$ & $-1.29^{\mathrm{NS}}$ & $0.36^{\mathrm{NS}}$ & $-0.01^{\mathrm{NS}}$ & $-0.70^{* * *}$ & $1.81^{\mathrm{NS}}$ & $2.01^{\mathrm{NS}}$ & $-0.44^{\mathrm{NS}}$ & $-4.34^{\mathrm{NS}}$ & $0.14^{\mathrm{NS}}$ & $-1.40^{* *}$ \\
\hline $\mathbf{P}_{1} \times \mathbf{P}_{3}$ & $-5.71^{* *}$ & $2.07^{* * *}$ & $2.77^{*}$ & $0.45^{*}$ & $0.00^{\mathrm{NS}}$ & $0.69^{* *}$ & $-4.65^{* *}$ & $-0.71^{\mathrm{NS}}$ & $-0.52^{*}$ & $-25.04^{* *}$ & $4.75^{*}$ & $-4.03^{* *}$ \\
\hline $\mathbf{P}_{1} \times \mathbf{P}_{4}$ & $-15.95^{* *}$ & $0.73^{\mathrm{NS}}$ & $-5.85^{* *}$ & $-1.07^{* *}$ & $-0.12^{* * *}$ & $0.41^{*}$ & $-4.70^{* *}$ & $-4.10^{* *}$ & $0.22^{\mathrm{NS}}$ & $-18.72^{*}$ & $-0.97^{\mathrm{NS}}$ & $1.50^{* * *}$ \\
\hline $\mathbf{P}_{2} \times \mathbf{P}_{3}$ & $2.91^{* * *}$ & $0.07^{\mathrm{NS}}$ & $-2.80^{*}$ & $-0.6^{* *}$ & $-0.04^{\mathrm{NS}}$ & $-0.48^{*}$ & $-0.11^{\mathrm{NS}}$ & $0.57^{\mathrm{NS}}$ & $-0.30^{\mathrm{NS}}$ & $10.71^{\mathrm{NS}}$ & $1.58^{\mathrm{NS}}$ & $0.85^{\mathrm{NS}}$ \\
\hline $\mathbf{P}_{2} \times \mathbf{P}_{4}$ & $-4.97^{* *}$ & $-1.27^{* *}$ & $-7.93^{* *}$ & $0.13^{\mathrm{NS}}$ & $0.01^{\mathrm{NS}}$ & $0.24^{\mathrm{NS}}$ & $-7.39^{* *}$ & $2.84^{*}$ & $-0.27^{\mathrm{NS}}$ & $-2.47^{\mathrm{NS}}$ & $1.37^{\mathrm{NS}}$ & $-0.12^{\mathrm{NS}}$ \\
\hline $\mathbf{P}_{3} \times \mathbf{P}_{4}$ & $-7.30^{* * *}$ & $-0.71^{\mathrm{NS}}$ & $1.17^{\mathrm{NS}}$ & $-0.16^{\mathrm{NS}}$ & $-0.15^{* *}$ & $-0.70^{* *}$ & $-3.11^{* *}$ & $9.12^{* * *}$ & $0.08^{\mathrm{NS}}$ & $69.63^{* * *}$ & $-0.90^{\mathrm{NS}}$ & $-0.01^{\mathrm{NS}}$ \\
\hline $\begin{array}{l}\text { LSD 5\% } \\
\text { (Sii-Sjj) }\end{array}$ & 4.66 & 0.72 & 2.24 & 0.39 & 0.07 & 0.35 & 1.79 & 2.06 & 0.42 & 16.79 & 3.91 & 0.17 \\
\hline $\begin{array}{l}\text { LSD 5\% } \\
\text { (Sij-Sik) }\end{array}$ & 7.38 & 1.13 & 3.55 & 0.62 & 0.11 & 0.55 & 2.82 & 3.26 & 0.66 & 26.55 & 6.18 & 0.28 \\
\hline
\end{tabular}

$\mathrm{NS}, *$, and $* *$ are insignificant, significant, and highly significant at 5\% and $1 \%$ levels of probability, respectively.

Table 5. Heterosis percentage over mid parent (MP) for growth, yield and quality traits of pea $F_{1}$ hybrids

\begin{tabular}{|c|c|c|c|c|c|c|c|c|c|c|c|c|}
\hline \multirow[b]{2}{*}{ Crosses } & \multicolumn{7}{|c|}{ Growth traits } & \multicolumn{3}{|c|}{ Yield and its components traits } & \multicolumn{2}{|c|}{ Quality traits } \\
\hline & $\begin{array}{c}\text { Plant } \\
\text { height } \\
\text { (cm) }\end{array}$ & $\begin{array}{c}\text { Branch } \\
\text { No. }\end{array}$ & $\begin{array}{c}\text { Plant } \\
\text { dry wt. } \\
\text { (gm) }\end{array}$ & $\begin{array}{c}\text { Pod } \\
\text { length } \\
\text { (cm) }\end{array}$ & $\begin{array}{c}\text { Pod } \\
\text { diameter } \\
(\mathrm{cm})\end{array}$ & $\begin{array}{c}\text { Seed } \\
\text { No./pod }\end{array}$ & $\begin{array}{c}\text { 100-Seed } \\
\text { wt.(gm) }\end{array}$ & $\begin{array}{c}\text { Pod } \\
\text { No/plant. }\end{array}$ & $\begin{array}{l}\text { Pod wt. } \\
\text { (gm) }\end{array}$ & $\begin{array}{c}\text { Yield/plant } \\
\text { (g) }\end{array}$ & $\begin{array}{c}\text { TSS } \\
\left(\text { Brix }^{\circ}\right)\end{array}$ & $\begin{array}{c}\text { Protein } \\
(\%)\end{array}$ \\
\hline $\mathbf{P}_{1} \times \mathbf{P}_{2}$ & $25.72^{* *}$ & $27.78^{* *}$ & $-23.73^{* *}$ & $2.77^{\mathrm{NS}}$ & $-4.00^{\mathrm{NS}}$ & $-9.80^{* *}$ & $-3.03^{\mathrm{NS}}$ & $9.52^{*}$ & $-16.33^{* *}$ & $-10.22^{\mathrm{NS}}$ & $9.72^{\mathrm{NS}}$ & $-12.85^{* *}$ \\
\hline $\mathbf{P}_{1} \times \mathbf{P}_{3}$ & $-16.51^{* *}$ & $62.50^{* *}$ & $7.51^{\mathrm{NS}}$ & $3.19^{\mathrm{NS}}$ & $-6.67^{\mathrm{NS}}$ & $7.41^{* *}$ & $-17.17^{* *}$ & $2.99^{\mathrm{NS}}$ & $-18.16^{* *}$ & $-17.19^{*}$ & $37.85^{* *}$ & $-30.33^{* *}$ \\
\hline $\mathbf{P}_{1} \times \mathbf{P}_{4}$ & $-36.97^{* *}$ & $21.05^{* *}$ & $-30.61^{* *}$ & $-13.87^{* *}$ & $-15.66^{* *}$ & $5.26^{*}$ & $-20.21^{* *}$ & $-10.56^{*}$ & $1.02^{\mathrm{NS}}$ & $-13.72^{\mathrm{NS}}$ & $-0.54^{\mathrm{NS}}$ & $4.71^{* *}$ \\
\hline $\mathbf{P}_{\mathbf{2}} \times \mathbf{P}_{3}$ & $4.99^{\mathrm{NS}}$ & $5.26^{\mathrm{NS}}$ & $-29.37^{* *}$ & $-10.50^{* *}$ & $-8.33^{*}$ & $-11.11^{* *}$ & $-6.73^{* *}$ & $13.67^{* *}$ & $-14.48^{* *}$ & $17.01^{*}$ & $22.71^{\mathrm{NS}}$ & $-0.56^{\mathrm{NS}}$ \\
\hline $\mathbf{P}_{2} \times \mathbf{P}_{4}$ & $-14.94^{* *}$ & $-22.73^{* *}$ & $-55.05^{* *}$ & $-2.16^{\mathrm{NS}}$ & $-5.00^{\mathrm{NS}}$ & $0.00^{\mathrm{NS}}$ & $-23.41^{* *}$ & $21.39^{* *}$ & $-9.95^{*}$ & $7.04^{\mathrm{NS}}$ & $10.40^{\mathrm{NS}}$ & $0.27^{\mathrm{NS}}$ \\
\hline $\mathbf{P}_{3} \times \mathbf{P}_{4}$ & $-21.33^{* *}$ & $-10.00^{\mathrm{NS}}$ & $-5.84^{\mathrm{NS}}$ & $-5.84^{*}$ & $-20.00^{* *}$ & $-9.80^{* *}$ & $-16.49^{* *}$ & $46.51^{* *}$ & $-2.07^{\mathrm{NS}}$ & $70.63^{* *}$ & $1.80^{\mathrm{NS}}$ & $-2.43^{* *}$ \\
\hline $\begin{array}{l}\text { LSD at } \\
5 \%\end{array}$ & 8.08 & 1.24 & 3.89 & 0.68 & 0.12 & 0.60 & 3.09 & 3.58 & 0.73 & 29.08 & 6.77 & 0.30 \\
\hline
\end{tabular}

$\mathrm{NS}, *$ and $* *$ are insignificant, significant, and highly significant at 5\% and $1 \%$ levels of probability, respectively. 


\section{Scientific Journal of Agricultural Sciences 3 (2): 78-86, 2021}

\section{DISCUSSION}

Analysis of variance of $4 \times 4$ of the diallel cross system in pea reflect highly significant mean squares for genotypes and also parents and crosses among them, except pod number/ plant, average pod weight, yield/ plant, and TSS for parents, average pod weight, and TSS for crosses, and TSS for genotypes (Table 1). Moreover, GCA and SCA mean squares were highly significant for all the studied traits, except branch number, average pod weight, and TSS for GCA, and TSS for SCA were appeared insignificant. Significant GCA and SCA mean squares for all the studied traits in pea were also revealed by Joshi et al. (2016),Suman et al. (2017), Hama-amin (2020), and Towfiq et al. (2020).

In this respect, general and specific combining ability estimates (GCA and SCA) help in the identification of the best combiner and promising parents and desirable crosses for the improvement of plant traits through selection and breeding. The variance of GCA and SCA identify the relative importance of additive and non-additive causes of variation (Amin and Haridy, 2019).

Therefore, the four parents crossed in this work; i.e., Cambados $\left(\mathrm{P}_{1}\right)$, Master B $\left(\mathrm{P}_{2}\right)$, Little Marvel $\left(\mathrm{P}_{3}\right)$, and Entsar $2\left(\mathrm{P}_{4}\right)$ had sufficient diversity. Similar results were also reported by Askander et al. (2018) and Gharib (2021).

\subsection{General combining ability}

The best combiners for growth traits (Table 3 ), which exhibited high GCA effect were $\mathrm{P}_{3}$ (Little Marvel) for plant height and $\mathrm{P}_{4}$ (Entsar 2) for dry weight/ plant.

Respecting yield and its component traits, the cultivars which showed high GCA effect were $\mathrm{P}_{4}$ (Entsar 2) for pod length and pod diameter, $\mathrm{P}_{1}$ (Cambados) for seed number/ pod, $\mathrm{P}_{2}$ (Master $\mathrm{B}$ ) for 100-seed weight, $\mathrm{P}_{3}$ (Little Marvel) for pod number/ plant andP ${ }_{2}$ (Master B) for yield/ plant. Concerning pod quality traits, $\mathrm{P}_{2}$ (Master $\mathrm{B}$ ) for protein content in seeds.

These results reflect the existence of favorable genes for all studied traits in the tested parental genotypes, which could be utilized in the breeding programs to improve pea. This finding is coherent with that of Kalia and Sood (2009).

Therefore, the performance of each trait was mainly cultivar-dependent. So that the choice of parents for a particular character should be based on its performance. Obtained results are in accordance with Askander et al. (2018) and Parveen et al., (2019).

\subsection{Specific combining ability}

For growth traits (Table 4), the crosses that showed high SCA effect were $\mathrm{P}_{1} \times \quad \mathrm{P}_{2}$
(Capados $\times$ Master $\mathrm{B}$ ) for plant height and $\mathrm{P}_{1} \times \mathrm{P}_{3}$ (Cambados $\times$ Little Marvel) for branch number and dry weight/ plant. According for yield and its components, the crosses that showed high SCA effect were $\mathrm{P}_{1} \times \mathrm{P}_{3}$ (Cambados $\times$ Little Marvel) for seed number/ pod and $\mathrm{P}_{3} \times \mathrm{P}_{4}$ (Little Marvel $\times$ Entsar 2)for average pod number/ plant and yield/ plant.

Concerning pod quality traits, the cross that $\begin{array}{lllll}\text { showed high } & \text { SCAeffect } & \text { wasP }_{1} \times & \mathrm{P}_{4}\end{array}$ (Cambados $\times$ Entsar 2) for protein content.

Similar results also showed that some crosses were observed superior for the SCA effects, indicating the presence of non-allelic interaction. These observed can be further utilized to develop and enhance the yield potential of pea cultivars and breeding programs(Suman et al., 2017).

\subsection{Heterosis}

In this respect, MP heterosis is mostly used in biometrical studies. The crosses which showed high MP values (Table 5) were $\mathrm{P}_{1} \times \mathrm{P}_{2}$ for plant height and $\mathrm{P}_{2} \times \mathrm{P}_{3}$ for branch number/ plant. For yield traits, the crosses having high MP values were $\mathrm{P}_{1} \times \mathrm{P}_{2}$ for pod length, $\mathrm{P}_{1} \times \mathrm{P}_{2}$ for seed number/ pod, $\mathrm{P}_{3} \times \mathrm{P}_{4}$ for average pod number/ plant, and $\mathrm{P}_{1} \times \mathrm{P}_{4}$ for average pod weight. Moreover, the crosses which showed high MP values in plant yield was $\mathrm{P}_{3} \times \mathrm{P}_{4}$. The best heterosis over MP in TSS was observed in the cross $\mathrm{P}_{1} \times \mathrm{P}_{3}$ which was reached $37.85 \%$. These results are in line with the finding of Hasan et al., (2010), Braret al., (2012) and Galal et al., (2019) who found positive heterosis in some studied crosses for horticultural traits of pea. These results indicated that heterosis did not reflect the GCA of the cross parents, but this is due to parent per se performance. Moreover, heterosis (MP) in plant yield reached to $70.63 \%\left(\mathrm{P}_{3} \times \mathrm{P}_{4}\right)$ and $17.01 \%\left(\mathrm{P}_{2} \times \mathrm{P}_{3}\right)$. So that transgresssivesegregants would be expected in the progeny of these crosses. And selection in advanced generation for high performed lines would be better than the better parent and /also than hybrid itself.

These results are in agreement with those byBrar et al. (2012), Galal et al. (2019), and Gharib (2021) which indicated that all studied traits showed significant mid-parent heterosis in the desired direction in some crosses. Also, all studied traits exhibited different types of potency ratios.

\section{CONCLUSION}

The obtained results indicated considerable genetic variations among the evaluated commercial pea cultivars as well as among the obtained $\mathrm{F}_{1}$ hybrids for all the studied traits. Accordingly, crossing followed by selection in segregating generations can be applied to develop new highyielding breeding lines. 


\section{REFERENCES}

Abo-Hamda EME (2019). Genetic analysis of some economic characters in pea. Egypt. J. Agric. Res., 97 (1): 229- 248.

Al-Hamdany HShY (2014). Estimation of heterosis, combining ability, gene action, genotypic and phenotypic correlation in pea (Pisum sativum L.). J. Agric. Sci., 10 (2): 19-28.

Amin KA, Haridy AGH (2019). Inheritance of some seed quality and assessment of soluble protein profiles in five pea (Pisum sativum L.) cultivars. Assiut J. Agric. Sci., 50 (2): 337-350.

Askander HS, Abdullah PA, Abdulrahman RIS (2018). Estimation some genetic parameters, combining ability andheterosis in pea (Pisum sativum) using half diallel cross. J. Univ.Duhok., 21 (1): 19-28.

Brar PS, Dhall RK, Dinesh (2012). Heterosis and combining ability in garden pea (Pisum sativum L.) for yield and its contributing traits. Vegetable Sci., 39 (1): 51-54.

El-Dakkak AAA (2016). Genetic improvement for yield and quality characters in pea by using selection. J. Plant Production, Mansoura Univ., 7 (8): 837-842.

Galal RM, Mohamed AG, Ismail EEM (2019). Genetic analysis of some crosses for yield and its components and earliness in pea (Pisum sativum L.). Egypt. J. Hort., 46 (1): 1-11.

Gharib HA, Amany M (2021). Inheritance of earliness, yield and its components in garden pea (Pisum sativum L.). Egypt. J. Appl. Sci., 36: 5-6.

Griffing B (1956).Concepts of general and specific combining ability in relation to diallel crossing system. Aust. J. Bio. Sci. 9: 463-493.

Hama-Amin TN (2020). Half diallel analysis of seven pea cultivars for seed yield and its components for $\mathrm{F}_{4}$ generation under Sulaimani condition. Iraqi J. Agric. Sci., 51 (2): 600-610.

Hamed AA, Hussein AH, Khalil EMEA (2015). Genetic studies on some quantitative traits in pea 1. Inheritance of vegetative characters, yield and its components. Egypt. J. Agric. Res., 93 (4): 12111229.

Hasan MNM, Abd El-Aty YY, Zayed GA, Abd El Lah HS (2010). Heterosis, correlation and gene action in some genotypes of pea (Pisum sativum L.). Minia $2^{\text {nd }}$ conf. Agric.Environ. Sci., 151-160.

Hassan SA (2012). Inheritance of earliness, dry matter and shelling in pea. Res. J. Agric. and Biol.Sci., 8(1):1-5.
Hayman BI (1954a). The theory and analysis of diallel crosses. Genetics, 34: 784-804.

Hayman BI (1954b). The analysis of variance of diallel table. Biometrics, 10: 235-244.

Joshi JD, Ravindrababus Y, Patel AM (2016). Diallel analysis in field pea [Pisum sativum (L.) vararvense]. Elect. J. Plant Breed., 7 (3): 611-619.

Kalia P, Sood M (2009). Combining ability in the $F_{1}$ and $F_{2}$ generations of a diallel cross for horticultural traits and protein content in garden pea (Pisum sativum L.). Sabrao J. Breed. Gnet., 41(1): 53-68.

Kumari P, Basal N, Singh AK, Rai VP, Srivastava CP, Singh PK (2013). Genetic diversity studies in pea (Pisum sativum L.) using simple sequence repeat markers. Genet. Mol.Res., 12: 35403550.

Manjunath B, Srinivasa DV, Hanumantappa M, Lakshmana D, Aghora TS (2020). Combining abilitystudies for yield and yield contributing traits in garden pea(Pisum sativum L.). Int. J. Curr. Microbiol. App. Sci., 9 (11):3261-3268.

Nassef M, Dalia T, El-Rawy MA (2013). Analysis of gene effects controlling some traits in pea (Pisum sativum L.). Aust. J. Basic Appl. Sci., 7 (1): 537 542.

Parveen N, Shakeel A, Malik TA, Awan FS (2019). Genetic studies for improving seed yield and quality traits including carotenoids, chlorophyll and protein contents in pea (Pisum sativum L.). Pak. J. Bot., 51 (6): 2105-2110.

Rai B (1979). Heterosis breeding. Agro-Biological publications, Delhi-110051, Indian, pp.183.

Smykal P, Aubert G, Bustin J, Coyne C, Ellis N, Flavell A, Warkentin T (2012). Pea (Pisum sativum L.) in the genomics era.Agronomy, 2 (2): 74-115.

Snedecor GW, Cochran WG (1967). Statistical methods. $6^{\text {th }}$ ed., Oxford and IBH Publication Co.

Suman H, Kumar B, Nageshwar M, Rathi I, Tamatam D (2017). Heterosis and combining ability for grain yield and yield associated traits in $10 \times 10$ Diallel analysis in pea (Pisum sativum L.). Inter. J. Current Microbiol. Appl. Sci., 6 (12): 15741585.

Towfiq ShI, Hama-Amin TN, Ahmed DA, Aziz OK (2020). Half diallel analysis for $F_{3}$ generation of pea (Pisum sativum L.) under Sulaimani condition, Iraq Kurdistan region. Iraqi J. Agric. Sci., 51 (3): 848-855. 


\section{الملخص العربي \\ القدرة علي التآلف وقوة الهجين لصفات المحصول والجودة في البسلة \\ هاني جمال زيادة، سمر عبد الله برديسي \\ قسم البساتين - كلية الزراعة - جامعة الزقازيق}

زيادة محصول البسلة وصفات الجودة هي الأهداف الأساسية لأي برنامج تربية، أجريت هذه الدراسة خلال ثلاثة مواسم نمو شتوية لأعوام

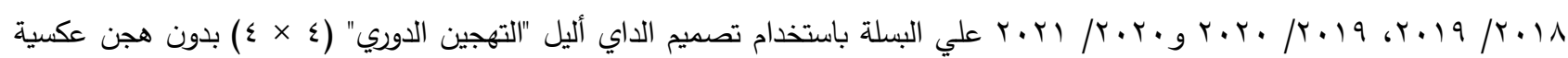
بكلية الزراعة، جامعة الزقازيق، مصر.

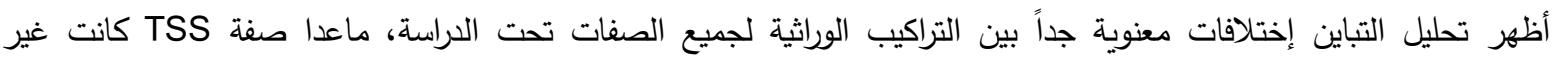

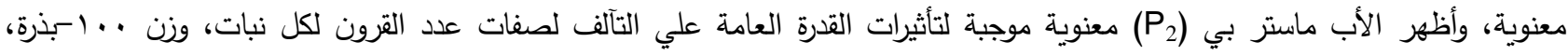
ولصفة الدصصول/ نبات، والأب انتصار r P (P4) لصفات ارتفاع النبات، الوزن الجاف للنبات، طول القرن، قطر القرن، وعدد البذور لكل

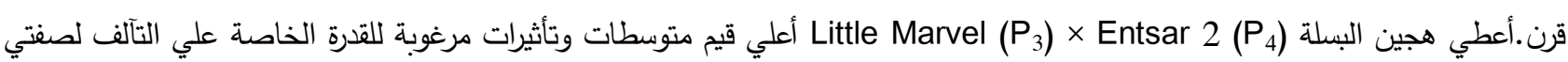
المحصول وعدد القرون لكل نبات.

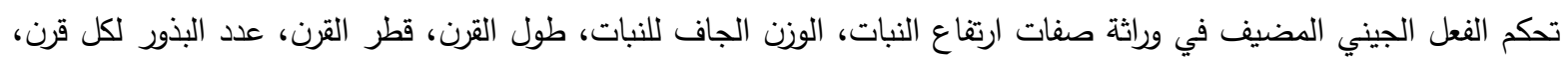

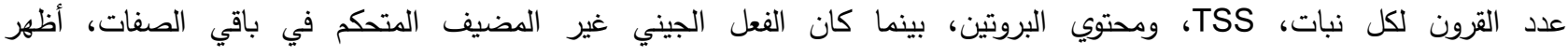
الهجينCambados $\left(P_{1}\right)$ × Little Marvel ( إيجابية ومعنوية لتأثيرات القدرة الخاصة علي التآلف لصفات عدد الأفرع/ نبات، الوزن

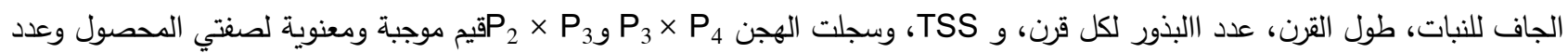

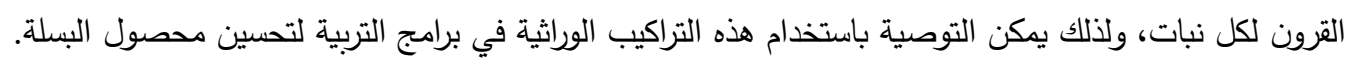

